\title{
The Authentic Assessment Based on Curriculum 2013 Carried by EFL Teacher
}

\author{
Yeni Novita Sari \\ Institut Agama Islam Negeri (IAIN) Bengkulu, Indonesia \\ yeninovitasaripauzi@gmail.com \\ Risnawati \\ Institut Agama Islam Negeri (IAIN) Bengkulu, Indonesia \\ risnawati.abdul@yahoo.com \\ Zelvia Liska Afriani \\ Institut Agama Islam Negeri (IAIN) Bengkulu, Indonesia \\ zelvia@iainbengkulu.ac.id
}

\begin{abstract}
In 2013 curriculum that is a new technique to students assessment. It is know as called authentic assessment. The purpose of this study is to describe the ability of English teachers at SMAN 04 Kota Bengkulu in applying authentic assessment in classroom learning activities. This research is a descriptive qualitative research. Researcher used three instruments, namely interview, observation, and documentation in collecting data. The English teachers at SMAN 04 Kota Bengkulu are already quite good at applying authentic assessment in English learning Activities. Application of authentic, the researcher uses a table equipped with nine indicators to optimize the understanding of the teacher in learning activities in the classroom. The results of observations in the classroom indicate that the authentic assessment carried out by the teacher shows that it is quite successful, which is included in the satisfaying category. It can be said that the two English teachers at SMAN 04 Kota Bengkulu were able to fulfill and implement authentic assessment. Research suggest that authentic assessment measures should take serious care. Then English teachers really need a lot of training to make them understand better in implementing authentic assessment.
\end{abstract}

Keywords : Authentic Assessment, Curriculum 2013, Analysis Student Worksheet, EFL Teacher

\section{A. Introduction}

Assessment is an important part of a teaching learning process that plays a big role in assessing or measuring students knowledge of learning. The assessment is an ongoing process that includes a variety of methodological techniques (Brown, H. D. (2004). On the other hand Assessments were made to get the information required by the administrator, teachers, staff developers, students, and parents to help determine the placement and activity Program In monitoring students' progress (O'Malley, M., \& Valdez-Pierce, L. (1996). Therefore, assessments are highly required to improve the learning and teaching process. There are several benefit in doing assessment. First, it is used to identify student qualifications in language. Second, it is used to determine the language skills and content area of the student competence in order to recommend an appropriate education Program. The last, it is used to 
determine whether students ' language skills and content area competencies are required to benefit from instruction at the class class level. Lastly,it is used to review the language and learning content area in the classroom.

There are several important objectives related to the assessment. The 2013 curriculum uses a new method of conducting assessments to students. It is called an authentic assessment. It is to see how teachers are able to evaluate student knowledge based on abilities that have a relationship in real-life experiences. So, an authentic assessment is a process for attracting problems that evaluate students not only from also their capabilities but also from previous processes. There are three types of authentic assessments that can be used in assessing language skills. They are performance-based assessments, portfolios, selfassessment, and peer-Assessment. From these three types of authentic assessments a teacher can choose an authentic type of assessment based on the need to assess which types of competencies. In other words, an authentic assessment encourages students to be ready to plunge in living in any situation in the real world. Found that an authentic assessment is a type of assessment that helps improve performance in students, because it authentically reflects the professional context of a real student.

There are three types of authentic assessments that can be used in assessing language skills. They are performance-based assessments, portfolios, self-assessment, and peerAssessment (O’Malley, J. M., \& Pierce, L. V. (1996). These assessments can be used to assess students language skills in specific language skills such as reading, writing, speaking and listening. From these three types of authentic assessments a teacher can choose an authentic type of assessment based on the need to assess which types of competencies. In other words, an authentic assessment encourages students to be ready to plunge in living in any situation in the real world. Found that an authentic assessment is a type of assessment that helps improve performance in students, because it authentically reflects the professional context of a real student.

There are several benefits of putting together an authentic assessment for teachers for students who are in line with the school curriculum. Approves the facts about helping students to apply their applications in real life, entrusting their understanding, and giving references to what they know. It can be said that this application proved to be able to help students understand material support well because this procedure is actually happening and used in real life. Then, students will try to apply this in the context of their lives when the 
Jadila: Journal of Development and Innovation

in Language and Literature Education

Publisher: Yayasan Karinosseff Muda Indonesia
E-ISSN: 2723-6900

P-ISSN: 2745-9578

Volume 1 Number 32021

Page: $377-388$

learning process is in the classroom. In other words, learning using authentic assessment has a meaningful meaning for students.

In this context, an authentic assessment is that the teacher will advise students when they are able to analyse teaching materials or perform a given task, then demonstrate the results of the analysis work and able to realize the weaknesses of what they have in following the learning in class. An authentic assessment will help students become themselves with a learning system that makes students accustomed to being forced to learn they do not like. It means that students sometimes learn only as fulfilment of formalities without them gaining the knowledge they can apply.

\section{B. Literature Riview}

\section{What is Authentic Assessment?}

A real-world task was developed for authentic assessment which involved the students in the processes such as identifying an issue from their community, planning to solve the issue, exploration and demonstration of their understanding to the community. This task was also planned to allow the students to integrate their knowledge, skills and attitude to analyze and understand the issue and design possible solutions (Gulikers, J., Bastiaens, T., \& Kirschner, P. (2004).. Authentic assessment in education has been a lot published by world experts in assessment exists along the continuum. It is because there are variations of task that is not traditional and not too authentic. The authentic continuum shows that assessments can extent the gap between artificial or situated on one hand and decontextualized or authentic the other hand.

Authentic assessment refers to assessment tasks that resemble reading and writing in the real world and in school. Its aim is to assess many different kinds of literacy abilities in contexts that closely resemble actual situations in which those abilities are used. For example, authentic assessments ask students to read real texts, to write for authentic purposes about meaningful topics, and to participate in authentic literacy tasks such as discussing books, keeping journals, writing letters, and revising a piece of writing until it works for the reader. Both the material and the assessment tasks look as natural as possible. Furthermore, authentic assessment values the thinking behind work, the process, as much as the finished product.

The authentic assessment is an assessment that uses or describes a variety of assessments that explain the learning, achievement, motivation, and attitudes of students in a class activity that is instrutionally relevant. There are three types Among other authentic assessments are 
Jadila: Journal of Development and Innovation in Language and Literature Education

Publisher: Yayasan Karinosseff Muda Indonesia
E-ISSN: 2723-6900

P-ISSN: 2745-9578

Volume 1 Number 32021

Page: $377-388$

performanceAssessment, portfolio, and student self-assessment (O'Malley, J. M., \& Pierce, L. V. (1996). Similar to the above opinion, the 2013 curriculum alsoIndicates that there are three types of authentic assessments:Performance, Port-folio, and project valuation. Then, authentic assessment will help students become themselves with a learning system that makes students accustomed to being forced into learning they don't like. it means that students sometimes learn only as fulfilling formalities without them getting the knowledge they can apply. Related to the advantages of authentic assessment, Williams added that students will not see the benefit of cheating because assessment activities will be specific to the given context focusing on real-world problems in a very specific and local context.

The benefits for students can express how well understanding the academic material they have learned and deepen their competency, such as collecting informers and linking learning with their own experiences In their world and the surrounding community (Mueller, Jon. 2006). As for teachers, an authentic assessment can help to be a benchmark on the ability of students and can see how effectively the methods given to students can be performed. Therefore, the authentic assessment application is as a tool of evaluation of learning outcomes at school or university level so that students are not just a learner, but as a form of achievement that is followed by Apply the skills they have to the real world.

\section{What is Curriculum 2013?}

The implementation of curriculum 2013 has resulted many changes in the process of teaching and learning activities, especially in English lesson. The change takes place as the teaching strategy, teaching material, and assesment.It can be said that the curriculum is a reference in the field of education that also has a relationship to how well participants learn and get results. Curriculum is a hope that is poured in the form of a plan and education program that will be implemented by the educators in the school. In system education system, the curriculum is a fundamental primary basis in the teaching and learning process. So, the curriculum can be interpreted as a plan that is used in the teaching and learning process involving educators and learners. Based on law No. 20 of 2003 Article 1 paragraph 19 on national education system, the curriculum is a set of designs or arrangements that has the purpose of learning, content, learning materials and methods used for reference to achieve on educational objectives. To realize the educational objectives, our country Indonesia has adopted a new curriculum that is 2013 curriculum. This 2013 curriculum will provide a new 
Jadila: Journal of Development and Innovation in Language and Literature Education

Publisher: Yayasan Karinosseff Muda Indonesia
E-ISSN: 2723-6900

P-ISSN: 2745-9578

Volume 1 Number 32021

Page: 377-388

goal that not only makes students smarter, but also trains them to be tough, physically healthy, and tolerant.

\section{K13 's Relationship with the Authentic Assessment?}

In the curriculum changes, assessments still remain one of the most important things because it is a process of activities to find out the competencies and abilities of students. Therefore, it is one of the most important aspects in the world of education. As a teacher, after the material delivered is finished in the class, teachers should conduct an assessment using the most accurate instruments, methods and procedures to get real information. So, $\mathrm{k} 13$ 's relationship with authentic assessment is to further activate students and introduce them to the real world.

\section{Research Method}

This study applied descriptive qualitative method. Descriptive qualitative method is a study which is the data analysis involves summarizing data in a dependable and accurate manner and leads to the presentation of study findings in a manner that has an air of undeniability given the narrative, descriptive, and non numerical nature of the data. In this study the researcher was focus on research in analyzing the issues of authentic assessment conducted by English teachers in the academic year 2020 at SMAN 4 Bengkulu city. In this study the researcher was see how English teachers in this school are implementing authentic assessment. collecting the data in this research, the researcher was used some methods of data collecting and research some such as observation, interview, and documentation were applied to obtain the data. 
Jadila: Journal of Development and Innovation in Language and Literature Education

Publisher: Yayasan Karinosseff Muda Indonesia
E-ISSN: 2723-6900

P-ISSN: 2745-9578

Volume 1 Number 32021

Page: $377-388$

\section{Finding and Discussion}

The results of research on observations, authentic assessment in learning English at SMAN 04 Kota Bengkulu were obtained through observation, interviews, and documentation analysis. The interview that was conducted was an integrated interview using new interviews. Then, document analysis was carried out on the lesson plan and syllabus. Then, this research was conducted on two English teachers at this school who had used the 2013 curriculum. Based on the researcher questions, the results of the researchers included how to implement assessment authentication based on curriculum 2013 at SMAN 04 Kota Bengkulu. Observation cheklist guideline :

Table 1

Authentic Assessment based on curriculum 2013 at SMAN 04 Kota Bengkulu

\begin{tabular}{|c|c|c|c|c|}
\hline No & $\begin{array}{l}\text { Research } \\
\text { Variabels }\end{array}$ & Component & Indicator & Items \\
\hline 1. & \multirow{7}{*}{$\begin{array}{l}\text { Authentic } \\
\text { Assessment }\end{array}$} & $\begin{array}{l}\text { Conducting professional } \\
\text { development. }\end{array}$ & $\begin{array}{l}\text { The teacher given an } \\
\text { assessment to student } \\
\text { after an explanation from } \\
\text { the teacher. }\end{array}$ & 1 \\
\hline 2. & & Building a team & $\begin{array}{l}\text { The teacher ask to } \\
\text { student the introfection } \\
\text { about self assessment. }\end{array}$ & 2 \\
\hline 3. & & Doing observation & $\begin{array}{l}\text { The teachers doing } \\
\text { observation until } \\
\text { activities. }\end{array}$ & 3 \\
\hline 4. & & $\begin{array}{l}\text { Collecting samples } \\
\text { assessment. }\end{array}$ & $\begin{array}{l}\text { The teacher focus on } \\
\text { feedback study. }\end{array}$ & 4 \\
\hline 5. & & $\begin{array}{l}\text { Adapting existing } \\
\text { assessment. }\end{array}$ & $\begin{array}{l}\text { The teacher focus on } \\
\text { assignment student. }\end{array}$ & 5 \\
\hline 6. & & $\begin{array}{l}\text { Adapting existing } \\
\text { technique. }\end{array}$ & $\begin{array}{l}\text { The teacher collects } \\
\text { student feedback }\end{array}$ & 7 \\
\hline 7. & & Trying out the assessment & $\begin{array}{l}\text { The teacher given ask to } \\
\text { student. }\end{array}$ & 6 \\
\hline
\end{tabular}

Based on the data that has been analyzed on table 1, it's that there are three data results obtained through the first interview data, second, checklist observation data, and the third data documentation. The following is an explanation of the three data results above: first, the results of interview data, from the interview data the researcher found that the two English teachers at SMAN 04 Bengkulu City had carried out the authentic assessment quite 
Jadila: Journal of Development and Innovation

in Language and Literature Education

Publisher: Yayasan Karinosseff Muda Indonesia
E-ISSN: 2723-6900

P-ISSN: 2745-9578

Volume 1 Number 32021

Page: $377-388$

well even though there were still obstacles. The two English teachers stated that the obstacles in carrying out the authentic assessment assessment at SMA 04 Bengkulu City were time constraints and constraints on the students themselves.

However, this did not become a barrier for the two English teachers to continue to carry out authentic assessments properly in accordance with the 2013 curriculum guidelines. Researchers saw that there was an imbalance between the interview data obtained and the actual data applied by the teacher in conducting the assessment. During the interview, both teachers stated that they used portfolio assessments, performance appraisals, and selfassessments. However, when the researcher analyzed the data on the lesson plan, one of the teachers only used two assessments, namely attitude assessment and self-assessment. Thus, researchers can conclude that there is still a lack of understanding of the teacher in implementing authentic assessment itself.

Second, from the data that the researcher obtained through checklist observation, the researcher found that two English teachers at SMAN 04 Bengkulu city had implemented authentic assessment quite well. In implementing authentic assessment, the two teachers have their own ways of applying authentic assessment to their students. Although the differences in these methods are very clear, the two English teachers have tried to apply the best possible authentic assessment according to the 2013 curriculum guidelines.

The biggest obstacle faced by these two teachers is the students themselves. In this case, the researcher saw that most students felt lazy and did not have a sense of responsibility for what they should do. Supposedly, if you want to be successful in carrying out authentic assessments, both parties must cooperate sincerely, as if the teacher gives assignments, students must have a sense of responsibility to do the assignments on time. So that with this collaboration, the authentic assessment carried out by the teacher to students will be helped easily and run as expected for the implementation of the authentic assessment properly.

The third is based on the findings of the researcher on the teacher's rpp regarding the assessment carried out by the English teacher at SMAN 04 Bengkulu city towards students, the researcher found that there were three types of assessment that the teacher used, namely performance assessment, portfolio assessment and self-assessment. Based on the theory used by the researcher, the two English teachers at SMAN 04 Kota Bengkulu had used the same type of assessment based on the theory that the researcher used to research the problems that 
Jadila: Journal of Development and Innovation

in Language and Literature Education

Publisher: Yayasan Karinosseff Muda Indonesia
E-ISSN: 2723-6900

P-ISSN: 2745-9578

Volume 1 Number 32021

Page: $377-388$

existed in SMAN 04 Kota Bengkulu. below are the findings of researchers in analyzing lesson plans.

The researcher found that the type of portfolio assessment can be seen from the attitude assessment which consists of responsibility in doing assignments, teamwork, and a sense of trust to God in all learning activities.Assessment performance is an assessment carried out to observe and assess students how they can get along and how they apply learning in class. student performance elements can be measured from the quality of their adjustment, skills in using tools, ability to analyze, and ability to read, draw, and use symbols. The researcher found that the last assessment used by the English teachers at SMAN 04 Kota Bengkulu was self-assessment. self-assessment is a self-learning assessment to motivate in solving problems faced in learning. This self-assessment can be measured by attitudes towards subjects, and attitudes towards teachers,

The finnaly is from the results of the analysis conducted by the researcher on the results of the students 'worksheets, the researcher found several problems in the students' worksheets. In this problem, the researcher found that: There was no direction in the student's assignment, there was no analysis description (content) in the question instructions. In making questions for student assignments, there are still errors in grammar. example: what can you see about paragraph two and four. According to the researcher, the sentence should be something like: what does mean idea from paragraph two and four. In making questions, there are still questions that do not end with a question mark. No number for each question, Do not use the reasons why the student answers the results.

So, authentic assessment is a form of assessment that asks students to show their achievements based on their performance in the real world, such as the application of their knowledge and skills. The basic principle of authentic assessment is that students must be able to apply or do what they have previously learned. Authentic assessment is a form of evaluation carried out in the 2013 curriculum. With this, there are some teachers who understand the concept of authentic assessment and have implemented authentic assessment in learning in schools, but there are also some teachers who are still confused about how we apply it due to lack of training. regarding authentic assessment. Based on the results of research obtained through questionnaires, interviews, document analysis, and observation, it shows that the two English subject teachers at SMAN 04 Bengkulu City have conducted authentic assessments in their learning. However, in practice it has not been fully 
Jadila: Journal of Development and Innovation

in Language and Literature Education

Publisher: Yayasan Karinosseff Muda Indonesia
E-ISSN: 2723-6900

P-ISSN: 2745-9578

Volume 1 Number 32021

Page: $377-388$

implemented properly due to a lack of training on authentic assessment so that there are still teachers who do not understand the concept of authentic assessment. Researchers saw that there was a lack of teacher understanding of the concept of authentic assessment from the results through interviews and observation.

Based on the results of interviews and observation, the teachers studied stated that they did not understand the concept of authentic assessment. In fact, they still asked what kind of authentic assessment was during the interview process. Sufficient knowledge and understanding are needed to properly apply authentic assessment. If the knowledge and understanding have not been fulfilled, then the application of the assessment cannot be carried out properly.

\section{E. Conclusion}

Based on research finfing and discussion the conclusion is authentic assessment is a form of assessment that asks students to show their achievements based on their performance in the real world, such as the application of their knowledge and skills. The basic principle of authentic assessment is that students must be able to apply or do what they have previously learned. Authentic assessment is a form of evaluation carried out in the 2013 curriculum. With this, there are some teachers who understand the concept of authentic assessment and have implemented authentic assessment in learning in schools, but there are also some teachers who are still confused about how we apply it due to lack of training. regarding authentic assessment. Based on the results of research obtained through questionnaires, interviews, document analysis, and observation, it shows that the two English subject teachers at SMAN 04 Bengkulu City have conducted authentic assessments in their learning. However, in practice it has not been fully implemented properly due to a lack of training on authentic assessment so that there are still teachers who do not understand the concept of authentic assessment. Researchers saw that there was a lack of teacher understanding of the concept of authentic assessment from the results through interviews and observation.

Based on the research results it is known that the teachers at SMAN 04 Bengkulu City have implemented authentic assessment. with the assessment models that they have implemented, including portfolio assessment, performance assessment, and self-assessment. Based on these three types of assessment, the researcher concluded that the teachers were said to be good when they applied it in English lessons even though there was one teacher 
who still had mistakes when setting grades. then in making lesson plans, especially in the assessment section, there are still teachers who don't really pay attention to the assessment rubric. so, one of the English teachers at SMAN 04 Kota Bengkulu did not complete all the lesson plans components in the assessment section. In addition, there are also those who are able to make assessments according to the 2013 curriculum and also apply authentic assessments in teaching and learning activities which can be said to be running quite well. English teachers make assessments in their lesson plans with the 2013 curriculum syllabus guide. They are able to complete all authentic assessment assessments based on the 2013 curriculum such as behavior assessments, knowledge assessments and skills assessments. On the other hand, there are obstacles in making skills assessment rubrics.

So, based on the results of the data, the teachers studied stated that they did not understand the concept of authentic assessment. In fact, they still asked what kind of authentic assessment was during the interview process. Sufficient knowledge and understanding are needed to properly apply authentic assessment. If the knowledge and understanding have not been fulfilled, then the application of the assessment cannot be carried out properly.

With the results of this study, the researcher does not intend to criticize the application of authentic assessment based on the 2013 curriculum at SMAN 4 Bengkulu City. However, with the results of such research, we get the result that authentic assessment must be taken positively by trainers based on the 2013 curriculum, schools, teachers, and education practitioners in order to provide better solutions for the recovery of the implementation of authentic assessment based on the 2013 curriculum. The 2013 curriculum trainers must provide a better solution to the difficulties of teachers in carrying out authentic assessments based on the 2013 curriculum. They need to conduct more training programs, especially on authentic assessment based on the 2013 curriculum.

Suggestions for the school, the school should accommodate or meet the needs of teachers in understanding authentic assessment based on the 2013 curriculum. In other words, schools should hold more workshops to improve teacher understanding regarding assessments based on the applied curriculum. And the school should not only carry out workshops and seminars, but the school must also have a program where teachers gather, discuss their problems in the teaching and learning process, and discuss the best solutions to 
Jadila: Journal of Development and Innovation in Language and Literature Education

Publisher: Yayasan Karinosseff Muda Indonesia
E-ISSN: 2723-6900

P-ISSN: 2745-9578

Volume 1 Number 32021

Page: 377-388

these problems. So, with this, the teachers will be a little helped by the lack of understanding they have faced so far.

There for, suggestions for English teachers are to enrich themselves with various types of learning media, activities, strategies, and resources. To enrich their knowledge and information, English teachers must actively participate in workshops, workshops or training programs. So along with the development of technology and information, the internet can be used as a source for teachers to develop their teaching. Also, they should improve their ability to use English instead of using more Indonesian and regional languages. Because based on the curriculum, 13 teachers are required to use more English in delivering material and communicating with students. Then, teachers and students should have an agreement in the teaching and learning process in advance in order to achieve the goals of each teaching and learning process that will be carried out. as educators must be open-minded to new curriculum concepts, to learning strategies, to methods that will always develop as a result of technological developments from time to time. And also the teacher must have a patient nature so that he can always learn to accept everything, be it about comments, input, or criticism, be it from students or the school environment with the aim of being better and increasing one's competence and ability as a professional teacher. .

Finally, suggestions for educators such as universities should train their students, especially those who take part in educational programs so that in the future they can improve the competence of teachers who know what their duties and obligations are. Furthermore, education practitioners must pay attention to curriculum implementation. Their opinion is needed as a recommendation to the government to increase the efforts of teachers in implementing the curriculum based on the 2013 Curriculum regulations.

\section{References}

Basuki, I., \& Hariyanto. (2014). Asesmen pembelajaran. Bandung: PT Remaja Rosdakarya.

Bolat, Y., \& Memet, K. (2017). Design implementation and authentic assesment of a unit according to concept based interdiciplinary approach. International Electronic Journal of Elementary Education (IEJEE). 1(1).1

Brown, H, D., and Abeywickrama. (2010). Language assessment principles and classroom practices (second edition).

Wahyuni, E., \& Gede, L. (2016). The authenticity of learning assessment : Study of teacher assessment practices in school vocation.

Imansyah. (2012). The Implementation of authentic assessment in SMAN 1 Bolo in the Aademic Year 2010/2011. Thesis of Undiksha. 
Ojung, J., \& Alida, D. (2017). A survey of uthentic assesment used to evaluate english language learning in nandi central sub-couty secondary school, Kenya, Baraton Interdisciplinary Research Journal, 7(1), 1.

Kemendikbud. Permendikbud Nomor 66 Tahun2013 tentang Standar Penilaian Pendidikan. Jakarta: Kementrian Pendidikan dan Kebudayaan RI.2013.

Kementerian Pendidikan dan Kebudayaan Republik Indonesia. (2013). Peraturan Menteri Pendidikan dan Kebudayaan No. 81a tentang Implementasi Kurikulum 2013. The Ministry of Education and Culture, Jakarta, Indonesia.

Kunandar, Penilaian Autentik (Penilaian Hasil Belajar Peserta Didik Berdasarkan Kurikulum 2013): Jakarta, PT RajaGrafindo Persada. Hlm.35

Gay, L.R. (2012). Education research: Competencies analysis and application-third edition. New York, Pearson.

Marhaeni, A.A.I.N. (2010). Orasi ilmiah pengenalan guru besar tetap Undiksha

Mueller, J. 2006. Authentic Asessment. North Central College. Tersedia: http://jonatan.muller.faculty.noctrl.edu/toolbox/whatisist.htm diakses pada Senin, 04 November 2013.

Nurgiantoro Suyata. 2010. Pengembangan Model Penilaian Otentik Dalam Pembelajaran Bahasa. Online source:http://staff.uny.ac.id

O'Malley, M., \& Valdez-Pierce, L. (1996). Authentic assessment for English language learners (p. 1-269). Addison-Wesley Publishing Company.

O’Malley, J. M., \& Pierce, L. V. (1996). Authentic assessment for English language learners: practical approaches for teachers. Massachusetts: Addison Wesley Publishing Company

Reynisdóttir. B. B. The efficacy of authentic assessment a practical approach to second language testing. University of Iceland School of Humanities Department of English.

Robert, K Y. Qualitative research from start to finish, New York, The Guilford Press, 2011,p.8.

Whitelock, D., \& Cross, S. (2012). Authentic assessment: What does it mean and how is it instantiated by a group of distance learning academics? International Journal of EAssessment, 2(1), 9.

Wortham, S. C. (2008). Assessment in early childhood education (5th ed.). Upper Saddle River, N.J: Pearson/Merrill Prentice Hall. 